DOI: 10.17951/lrp. 2017.36.4.181

\author{
Marek Pytlak
}

Uniwersytet Technologiczno-Humanistyczny w Radomiu

\title{
WPŁYW ROZWOJU \\ I MASOWEGO ROZPOWSZECHNIANIA SIE OSOBISTYCH URZĄDZEŃ CYFROWYCH NA ZACHOWANIA DZIECI I MŁODZIEŻY W SZKOLE
}

\begin{abstract}
Streszczenie: Ściąganie w czasie lekcji i przy odrabianiu prac domowych w polskiej oświacie było obecne od dawna. Obserwowany obecnie rozwój urządzeń cyfrowych podłączonych do Internetu nie tylko zwiększył znacznie skalę tego zjawiska, ale jednocześnie spowodował zmianę postawy młodego pokolenia. $Z$ wypowiedzi uczniów wynika, że jeżeli tylko mogą uniknąć samodzielnej pracy, to ściągają wszyscy i robią to często.
\end{abstract}

Słowa kluczowe: Brainly, ściąganie, plagiat, system edukacji

\section{WPROWADZENIE}

W ciągu ostatnich kilkudziesięciu lat nastąpił gwałtowny rozwój i rozprzestrzenienie się w społeczeństwie polskim wszelkich urządzeń opartych na technice cyfrowego przetwarzania informacji. Szkolnictwo szybko dostrzegło potrzebę edukacji młodzieży w dziedzinie wykorzystania tych urządzeń. Od końca lat 80. XX wieku (w zasadzie od 1986 roku) szkoły zaczęły kupować sprzęt komputerowy i stopniowo tworzyć szkolne pracownie komputerowe. Najpierw były to importowane ośmiobitowe mikrokomputery Spectrum. Później, od 1987 roku, ówczesne Ministerstwo Edukacji Narodowej kupowało produkowane przez wrocławskie zakłady Elwro pracownie ośmiobitowych mikrokomputerów Elwro 800 Junior. Na początku lat 90. XX wieku wszystkie szkoły średnie miały już pracownie komputerowe wraz $\mathrm{z}$ dostępnym w owym czasie oprogramowaniem. W ramach tych zakupów szkoły otrzymywały 15 stanowisk komputerowych połączonych w sieć. Pod koniec lat 90. $\mathrm{XX}$ wieku nastąpiła gwałtowna rozbudowa tej bazy sprzętowej i szkoły zaczęły 
wyposażać pracownie w szesnastobitowe komputery kompatybilne z IBM PC (Kiedrowicz 2009, s. 28). Unowocześnianie i wzbogacanie bazy technicznej trwa do dzisiaj. Teraz komputery w coraz szerszym zakresie wykorzystywane są też poza pracownią komputerową, czyli w zasadzie w każdej sali lekcyjnej. Nauczyciele korzystają z laptopów wraz z takimi urządzeniami peryferyjnymi jak rzutniki czy tablice multimedialne. Kolejnym przełomem jakościowym było podłączenie szkolnych komputerów do Internetu. Każda szkoła ma obecnie swoją stronę internetową, a wiele placówek zrezygnowało z dzienników lekcyjnych papierowych na rzecz ich wersji elektronicznej. Dzięki temu rodzice mogą na bieżąco śledzić postępy w nauce i zachowaniu swoich pociech.

\section{URZĄDZENIA CYFROWE WE WSPÓŁCZESNEJ SZKOLE}

Od 2015 roku technologie informacyjne w polskiej szkole są obecne na każdym poziomie kształcenia oraz wykorzystywane do realizacji zadań ze wszystkich przedmiotów nauczanych w szkołach na każdym poziomie kształcenia. Są wyodrębnione przedmioty szkolne, które mają zapoznawać dzieci i młodzież z wykorzystaniem nowoczesnych technologii, takie jak zajęcia komputerowe w kształceniu wczesnoszkolnym i klasach 4-6, informatyka czy technologie informacyjne na kolejnych etapach kształcenia. Oprócz tych zajęć nauczyciele innych przedmiotów wykorzystują w swojej dziedzinie komputery oraz Internet. Często zadawane są prace domowe, do których wykonania niezbędny jest komputer z dostępem do Internetu. Oprócz komputerów PC (inne typy komputerów, np. firmy Apple, spotykane są w Polsce sporadycznie) do wyszukiwania informacji uczniowie coraz częściej stosują smartfony i tablety. Ministerstwo miało plan wyposażenia uczniów w laptopy wraz z elektronicznymi wersjami potrzebnych podręczników i innych niezbędnych materiałów edukacyjnych, lecz plan ten nie został zrealizowany. Powszechnie uważa się, że młode pokolenie, będące aktualnie w wieku szkolnym, w większości świetnie sobie radzi w cyfrowym świecie. Popularność i codzienne korzystanie przez młodzież z takich portali, jak Facebook, Nasza Klasa czy Allegro zdaje się to potwierdzać. Stąd ogólny wniosek, że wykluczenie cyfrowe nie powinno zagrażać absolwentom polskich szkół. 


\section{ZAGROŻENIA WYNIKAJĄCE Z ROZWOJU TECHNOLOGII INFORMACYJNYCH}

Badania przeprowadzone na uczniach w polskich gimnazjach i liceach potwierdzają głębokość i istotność zachodzących zmian.

Jak zmienia się życie codzienne, gdy do gry wchodzą nowe media? Nabiera niespotykanej wcześniej intensywności. Kontakty twarzą w twarz zostają wzbogacone o uwagę poświęcaną sobie przez telefony komórkowe, komunikatory internetowe, serwisy społecznościowe i blogi. Na fizyczną przestrzeń bezpośrednich kontaktów nakłada się cyfrowa przestrzeń przepływu informacji, treści i emocji, do której zawsze można się wpiąć za pomocą przenośnych gadżetów (Halawa 2010).

Obecnie, obserwując sytuację w świecie realnym i w świecie wirtualnym, dostrzegamy pewne niekorzystne symptomy związane z wszechobecnością w życiu młodego pokolenia urządzeń cyfrowych. Możemy już zacząć się zastanawiać, czy lekarstwo, które miało poprawić nowoczesność i efektywność kształcenia, nie powoduje właśnie w szkolnictwie bardzo groźnych skutków ubocznych. Rodzice i nauczyciele alarmują, że spada drastycznie motywacja do nauki szkolnej. Wypowiedzi dzieci i nastolatków formułowane w stylu „po co mam się tego wszystkiego uczyć, przecież można to znaleźć w Internecie” oddają w zarysie ten coraz powszechniejszy u młodzieży sposób myślenia. I nie chodzi tu niestety o to, że dzieci zamiast w encyklopedii czy podręcznikach wolą wyszukiwać informacje $\mathrm{w}$ internetowej wyszukiwarce.

Nowe technologie cyfrowe dają uczniom dostęp do narzędzi, o których ich poprzednicy w szkolnych ławkach mogli tylko pomarzyć. Dostęp do informacji w dzisiejszych czasach staje się nieograniczony i natychmiastowy. Ale i to współczesnym uczniom nie wystarcza. Pojawiło się w szkołach nowe pokolenie uczniów, którzy nie są zainteresowani zrobieniem czegokolwiek samodzielnie. Nie chcą już wyszukiwać w Internecie treści materiałów czy informacji potrzebnych do rozwiązywania ich szkolnych problemów. Coraz powszechniejsza staje się wśród młodzieży postawa, która przejawia się tym, że wszystko, co jest do zrobienia, zrobią za nich inni. Mogą to być koledzy z klasy lub anonimowi podpowiadacze z Internetu. Coraz częściej nie kryjąc się względem kolegów i koleżanek, spisują prace domowe, a w świecie wirtualnym skupiają swoją aktywność na wyszukaniu osób, które za nich wykonają zadane w szkole zadania.

W Internecie od dawna funkcjonowały strony, z których można było ściągnąć gotową, napisaną przez kogoś innego pracę domową. Ściąga.pl (archiwum gotowych prac), PracaDomowa24.pl (opisz zadanie, które musisz rozwiązać i czekaj na pomoc 
innych), Zalicz.net (darmowe rozwiązanie pracy domowej, szkoła podstawowa, gimnazjum, liceum, studia), Odrabiamy.pl (zadania domowe w zasięgu twojej ręki!) i wiele innych. Już same hasła, którymi reklamują się oficjalnie te strony, powinny wzbudzać niepokój. Korzystanie z tych stron wymaga jednak samodzielnego wyszukiwania wśród wielu gotowych rozwiązań i później oceny poprawności znalezionej odpowiedzi.

Powszechnie dostępny Internet, który daje możliwość dotarcia do ogromnej rzeszy odbiorców, spowodował, że pojawiły się oferty pisania za pieniądze wszelkich prac: zaliczeniowych, okresowych, prezentacji maturalnych, licencjackich, magisterskich i doktorskich. Zawsze było to traktowane jako niezgodne z prawem, czyli jako próba oszustwa, ale wymiar sprawiedliwości nie radził sobie z tym zjawiskiem. Proceder ten jednak na tyle się rozwinął, że masowość zjawiska doprowadziła do zmiany zasad zdawania egzaminu maturalnego z języka polskiego.

Bardzo pomocne w rozwiązywaniu nawet bardzo skomplikowanych problemów były i są nadal fora dyskusyjne pasjonatów danej dziedziny wiedzy: komputerów, programowania, gier komputerowych, fotografii, motoryzacji i innych. $\mathrm{Na}$ forach prowadzą dyskusje pasjonaci, zatem trzeba mieć jakąś wiedzę bazową, żeby sensownie zadać pytanie i otrzymać satysfakcjonującą odpowiedź. Jeżeli ktoś pytał o rzeczy proste, to dostawał tylko zniechęcającą odpowiedź, że to już było wiele razy i żeby użył wyszukiwania. Dla części młodych ludzi to zbyt wiele. Chcą działać szybciej, łatwiej i bez wysiłku. Dla nich powstała w 2009 roku strona Zadane.pl.

\section{PORTAL ZADANE.PL}

Zadane.pl to strona, na której można zadać pytanie i szybko otrzymać odpowiedź lub przeszukać bazę gotowych rozwiązań problemów. Portal rozwinął się bardzo szybko i to stało się podstawowym elementem jego biznesowego sukcesu. Żeby otrzymać odpowiedź na zadane pytanie niezwłocznie (na 90\% zadanych pytań odpowiedź pojawia się już w ciągu 10 minut), muszą być osoby rozwiązujące. Do podejmowania działań na tej płaszczyźnie zachęca regulamin portalu. Pierwsze pytanie można zadać za darmo i zapłacić za nie otrzymanymi w czasie rejestracji punktami, ale odpowiedzi na kolejne pytania muszą być opłacone punktami zdobytymi przy rozwiązywaniu cudzych problemów. To oczywiście teoria, bo większość zadających pytania nie próbuje nawet czegokolwiek rozwiązywać. Przecież wystarczy skorzystać z dodatkowej możliwości i kupić punkty, płacąc za nie za pomocą SMS-a. Jest jednak grupa użytkowników zmotywowanych do intensywnej pracy umysłowej nad rozwiązywaniem zadań. To 90 moderatorów i grono prymusów walczących w rankingach pokazujących, kto udzielił najwięcej poprawnych odpowiedzi. Czołowe miejsca w rankingach są nagradzane. 
Co ciekawe, strona o takiej funkcjonalności wystartowała w Polsce. Po sukcesie w naszym kraju firma tworząca Zadane.pl rozpoczęła ekspansję światową pod nazwą Brainly. $Z$ materiałów prasowych tej firmy możemy się dowiedzieć, że obecnie funkcjonuje w ponad $35 \mathrm{krajach}$ na świecie, ma 12 wersji językowych, zatrudnia 450 moderatorów czuwających nad poprawnością merytoryczną, 30 milionów uczniów miesięcznie odwiedza strony serwisu, minimum 10 tysięcy pytań z różnych dziedzin wiedzy jest zadawanych co godzinę. Podstawowe rynki, na których firma jest obecna ze swoją wersją serwisu, to USA, Rosja, kraje Unii Europejskiej i tak dla nas egzotyczne jak Indonezja czy Ekwador (Press Kit Firmy Brainly 2015).

Takie strony jak Zadane.pl są według mnie ogromnym zagrożeniem dla normalnego funkcjonowania polskiej oświaty. Możliwość uzyskania rozwiązania szkolnych zadań na urządzeniach mobilnych od innych użytkowników niemal $\mathrm{w}$ czasie rzeczywistym zaburza $\mathrm{w}$ znacznym stopniu proces nauczania-uczenia się. Moje obserwacje zachowań i sposobu działania użytkowników tego portalu to potwierdzają. Nowe zjawisko całkowicie wypacza relacje między uczniami a nauczycielem, a jego skala jest już bardzo niepokojąca. Firma Gemius.pl monitorująca zjawiska w polskim Internecie umieściła w ostatnim raporcie z listopada 2015 roku portal Zadane.pl na trzecim miejscu pod względem ilości użytkowników w kategorii edukacja. Więcej użytkowników miały w tej kategorii tylko Wikipedia i Google. Portal podaje, że ma ok. 4 mln unikalnych użytkowników miesięcznie. Zamiast zdrowej relacji mistrz-uczeń mamy coraz częściej zabawę w policjantów i złodziei. Systematyczne korzystanie z wyręczania się pracą innych we wszystkich szkolnych obowiązkach prowadzi do wtórnego analfabetyzmu wśród młodzieży. Przykłady zadań przysyłanych do rozwiązania na stronę Zadane.pl wiele mówią o poziomie osób oczekujących pomocy i ich motywacji do jakiegokolwiek własnego działania i najlepiej potwierdzają tę tezę (pisownia oryginalna):

- „Omów wybżerze bałtyku”;

- „Ilustracje przedstawiają szkielety wybranych zwierząt kręgowych $\mathrm{Na}$ każdej Z ilustracji zamaluj na zielono czaszkę, a na niebiesko kręgosłup”;

- „Siemka potrzebna mi kartka świateczna wykonana w Gimpie Wielkie dzieki";

- „Czym sie odżywia lucki płud ?”;

- „rozwój sprzętu komputerowego do 1945”;

- „jutro mam kartkówke przydawka i doprlnienie może ktoś miał tą kartkówke i wie mniej więcej co na niej jest pls pomorzcie A jak nikt nie wiem to chociaż mi wytlumaczcie";

- „Spójrz na mapę polski .w jakim kierunku jedziemy:: a) z łodzi do Krakowa b) z Koszalina do kdańska c) z Warszawy do łodzi ?? Klasa 4"; 
- „NAPISZE KIM BYLI : Prof. Farfala, Pani Lilkowska, Prof. Tymoteusz Misiak, PLIS TO NA JUTRO!!!!!! DAJE NAJ!!!!!!!!!!! „Sposób na Alcybiadesa" Napiszcie kim byli i czego uczyli.";

- „Podajcie jak macie sprawdzian grupa A i B „ciepło i cząsteczki” klasa 2 gim, TO JEST FIZYKA 2. Proszę... Powinno być około 29 zadań. Dam najj. Nie chcę linków";

- „Zaznacz w pustyni u w puszczy najwazniejsze wedrowki stasia i nel strony lub rozdzialy";

- „Napisz opis krajobrazu który widzisz za oknem”;

- „Co to jest film niemy Błagam !";

- „Ludzie pomóżcie, daje naj ! Proszę o przetłumaczenie takich dat , jak: 1521, 1545,1573,1596";

- „Opisz swoją drogę ze szkoły do domu w taki sposób aby zauważyć uwagę na zwyczajne rzeczy";

- „Napisz list do papieża jako zwierzchników krzyżaków ze skargą na to co zrobili Jurandowi

Błagam !!! Może być krótki SZYBKO <3 DAJE NAAJ";

- „napiszcie wszystko o ksiaszce Władca pierscieni wszystkie czesci plis daje naj” Źródło: www.zadane.pl

Nauczyciele próbują zapobiec wykorzystywaniu plagiatów przez uczniów przynajmniej tam, gdzie jest to możliwe. Zadanie „Opisz lot balonem nad szkołą na $3 / 4$ strony” jest trudne do napisania dla kogoś, kto nie widział danej szkoły, ale z matematyki czy innych przedmiotów nie da się tak sformułować pracy domowej. Najwięcej zadań jest wstawianych z matematyki, języka polskiego i angielskiego. W monitorowanym okresie wyjątkowo mało było zadań z fizyki. Aktywność zalogowanych użytkowników waha się od 1000 wcześnie rano (ok. godziny 7) do kilkunastu tysięcy w godzinach popołudniowych, kiedy najwięcej osób odrabia prace domowe. $\mathrm{W}$ wakacje ruch na portalu zamiera. Tabela 1 pokazuje wzrost zainteresowania korzystaniem z portalu przez zestawienie wyników moich obserwacji z 2013 roku i 2015 roku. Widać znaczący wzrost liczby pytań zadawanych przez użytkowników.

Tabela 1. Podział pytań ze względu na tematykę przedmiotową.

Porównanie wyników z roku 2013 i 2015

\begin{tabular}{|l|c|c|}
\hline Przedmioty & $\begin{array}{c}\text { Ilość pytań wstawionych } \\
\text { w ciągu 1 godz. (10.12.2013, piątek, } \\
\text { godz. 19-20) }\end{array}$ & $\begin{array}{c}\text { Ilość pytań wstawionych } \\
\text { w ciągu 1 godz. (15.12.2015, wtorek, } \\
\text { godz. 19-20) }\end{array}$ \\
\hline matematyka & 60 & 145 \\
\hline język polski & 57 & 133 \\
\hline język angielski & 27 & 44 \\
\hline
\end{tabular}




\begin{tabular}{|l|c|c|}
\hline Przedmioty & $\begin{array}{c}\text { Ilość pytań wstawionych } \\
\text { w ciągu 1 godz. (10.12.2013, piątek, } \\
\text { godz. 19-20) }\end{array}$ & $\begin{array}{c}\text { Ilość pytań wstawionych } \\
\text { w ciągu 1 godz. (15.12.2015, wtorek, } \\
\text { godz. 19-20) }\end{array}$ \\
\hline historia & 19 & 36 \\
\hline informatyka & 12 & 5 \\
\hline biologia & 12 & 20 \\
\hline chemia & 11 & 19 \\
\hline fizyka & 4 & 10 \\
\hline sztuka & 6 & 5 \\
\hline inne & 14 & 79 \\
\hline
\end{tabular}

Źródło: opracowanie własne

Żeby poprawić swój wizerunek oraz zwiększyć zainteresowanie, portal Zadane.pl organizuje akcje i konkursy dla uczniów, takie jak olimpiada logiczno-matematyczna. Uczniowie podzieleni są na trzy kategorie: szkoły podstawowe, gimnazja i licea. Olimpiada przeprowadzana jest w dwóch etapach online. Nad wszystkim czuwają nauczyciele z uprawnieniami egzaminatorów maturalnych i gimnazjalnych. Ostatnia edycja otrzymała nawet patronat honorowy Ministerstwa Edukacji Narodowej.

\section{INNE PORTALE POMAGAJĄCE W ODRABIANIU PRAC DOMOWYCH}

Są też i inne strony o podobnym profilu. Jeżeli ktoś poszukuje rozwiązania zadania z podręcznika, to na stronie www.pracadomowa.pl je znajdzie. Wystarczy wybrać klasę i podręcznik, z jakiego się korzysta i już mamy wszystkie rozwiązania z całej książki. Intensywne korzystanie z TI powoduje, że wykonanie zadania domowego z matematyki, fizyki czy chemii zajmuje wtedy zaledwie kilka minut. W tym nowo powstałym serwisie internetowym można znaleźć zbiory opracowanych zadań z niemal wszystkich podręczników używanych w polskich szkołach. Strona oferuje ponad milion gotowych rozwiązań zadań szkolnych z przedmiotów ścisłych. Serwis przeznaczony jest dla dzieci i młodzieży ze szkół podstawowych, gimnazjalnych i ponadgimnazjalnych.

Wydaje się, że sytuacja jest już bardzo poważna i możliwe są dwa rozwiązania. Zaprzestanie zadawania prac pisemnych lub podjęcie walki z internetowymi portalami jawnie naruszającymi zasady etyczne. Portal Zadane.pl posiada w swoim archiwum 4819271 odpowiedzi za zadane pytania, czyli tyle razy doszło do niesamodzielnego odrabiania pracy domowej, a przecież są też tacy, którzy korzystają z rozwiązań widocznych na tej stronie i nie zadają swojego pytania. 


\section{POSTAWY MŁODZIEŻY OBSERWOWANE NA FORUM CZASOPISMA „VICTOR JUNIOR”}

O tym, co młodzież myśli na temat ściągania, próbowałem się dowiedzieć, analizując wpisy na forum czasopisma dla młodzieży „Victor Junior”. Na stronie http:// victor-junior.pl/forum/ znalazłem wątek Spisywanie prac domowych. Wyniki interpretacji tych wpisów przedstawione w tabeli 2 nie pozostawiają złudzeń: 36 osób na 62 badane (w sprawie ściągania innych 2 osoby się nie wypowiedziały), czyli $58,1 \%$, dostrzega wokół siebie powszechne codzienne ściąganie ze wszystkich przedmiotów i nie ma oporów, żeby o tym pisać.

Tabela 2. Wynik analizy wypowiedzi na forum Victor Junior w wątku Spisywanie prac domowych

\begin{tabular}{|c|c|c|c|c|c|c|}
\hline \multirow{2}{*}{ L.p. } & \multicolumn{6}{|c|}{ Spisuję: } \\
\hline & zawsze & często & rzadko & nigdy & przedmioty & co robią inni \\
\hline 1 & & & + & & mat. & wszyscy spisują na przerwach \\
\hline 2 & & + & & & wszystkie & wszyscy spisują \\
\hline 3 & & & & & pol. ang. & wszyscy spisują \\
\hline 4 & & & & + & & wszyscy matematykę \\
\hline 5 & & & + & & & wszyscy spisują \\
\hline 6 & & + & & & mat. & wszyscy spisują \\
\hline 7 & + & & & & pol., geogr. biol. & wszyscy spisują \\
\hline 8 & + & & & & & wszyscy spisują \\
\hline 9 & & & + & & & \\
\hline 10 & & & & + & & wszyscy spisują \\
\hline 11 & & & + & & & wszyscy spisują \\
\hline 12 & & & & + & & \\
\hline 13 & + & & & & mat. & \\
\hline 14 & & + & & & biol., inne & wszyscy spisują \\
\hline 15 & + & & & & fiz. & wszyscy spisują \\
\hline 16 & & & & + & & - \\
\hline 17 & & & & + & & wszyscy spisują \\
\hline 18 & + & & & & & wszyscy spisują \\
\hline 19 & & & + & & & wszyscy spisują \\
\hline 20 & + & & & & & wszyscy spisują \\
\hline 21 & + & & & & mat. & wszyscy spisują \\
\hline 22 & & + & & & & wszyscy spisują \\
\hline 23 & & & & + & & wszyscy spisują \\
\hline 24 & + & & & & & wszyscy spisują \\
\hline 25 & & & + & & & wszyscy spisują \\
\hline
\end{tabular}




\begin{tabular}{|c|c|c|c|c|c|c|}
\hline \multirow{2}{*}{ L.p. } & \multicolumn{6}{|c|}{ Spisuję: } \\
\hline & zawsze & często & rzadko & nigdy & przedmioty & co robią inni \\
\hline 26 & & + & & & & - \\
\hline 27 & & & & + & & wszyscy spisują \\
\hline 28 & & & & & & $\begin{array}{l}\text { matmy nie spisują, zabierane są } \\
\text { zeszyty przed pierwszą lekcją }\end{array}$ \\
\hline 29 & & & & + & & wszyscy spisują \\
\hline 30 & & & + & & & \\
\hline 31 & & & + & & & \\
\hline 32 & & & & + & & wszyscy spisują \\
\hline 33 & & + & & & & \\
\hline 34 & + & & & & & \\
\hline 35 & & & + & & & wszyscy spisują \\
\hline 36 & & + & & & hist., wos, fiz. & wszyscy spisują \\
\hline 37 & & & + & & & \\
\hline 38 & & & + & & & wszyscy spisują \\
\hline 39 & & & + & & & \\
\hline 40 & & & + & & & wszyscy spisują \\
\hline 41 & & & & + & & wszyscy spisują \\
\hline 42 & & & + & & & \\
\hline 43 & & + & & & mat., niem. & wszyscy spisują \\
\hline 44 & & & + & & & \\
\hline 45 & & & + & & & \\
\hline 46 & & & + & & & \\
\hline 47 & & + & & & & \\
\hline 48 & & & & + & & wszyscy spisują \\
\hline 49 & & & & + & & wszyscy spisują \\
\hline 50 & & + & & & & \\
\hline 51 & & & + & & & wszyscy spisują \\
\hline 52 & & + & & & & wszyscy spisują \\
\hline 53 & & & & + & & \\
\hline 54 & & & & + & & \\
\hline 55 & & & & + & & wszyscy spisują \\
\hline 56 & & + & & & & \\
\hline 57 & & + & & & & \\
\hline 58 & & & + & & & \\
\hline 59 & & & + & & & wszyscy spisują \\
\hline 60 & & & + & & & wszyscy spisują \\
\hline 61 & & + & & & mat. & \\
\hline 62 & & + & & & & \\
\hline
\end{tabular}

Źródło: opracowanie własne 
Tabela 3. Podsumowanie wyników zestawionych w tabeli 2.

\begin{tabular}{|l|c|c|}
\hline \multicolumn{2}{|c|}{ Ściągam: } & udzial \% \\
\hline zawsze & 9 & $15 \%$ \\
\hline często & 15 & $25 \%$ \\
\hline rzadko & 21 & $35 \%$ \\
\hline nigdy & 15 & $25 \%$ \\
\hline razem & 60 & $100 \%$ \\
\hline
\end{tabular}

Źródło: opracowanie własne

Młodzież nie tylko otwarcie przyznaje, że ściąganie jest nagminne, ale z wypowiedzi można wysnuć wniosek, że jest to normalne zachowanie w szkole. Wypowiedzi na forum dotyczyły spisywania od kolegów prac domowych, odbywającego się w szkole przed zajęciami i w czasie lekcji. Jeżeli do tego dodamy tych, którzy mają odrobioną pracę domową dzięki takim portalom jak Zadane.pl, to odsetek samodzielnie odrabiających prace domowe jeszcze znacząco spadnie. Przecież „po szkole można pozostać w kontakcie - zeszyt z zadaniem domowym leży koło komputera, na którym toczy się jednocześnie kilka rozmów ze znajomymi” (Halawa 2010).

\section{WYKORZYSTYWANIE KOMUNIKATORÓW PRZEZ MŁODZIEŻ}

Dzieci i młodzież uznają za normalne zachowania, które w ocenie dorosłych budzą raczej mieszane uczucia. Po powrocie do domu dzieci nie tracą ze sobą kontaktu. Przecież wystarczy uruchomić komunikator Skype i można rozmawiać z kolegami (koleżankami), siedząc przy własnym biurku. Tak też można wymieniać się pomysłami, odrabiając prace domowe. To kolejna okazja do pracy grupowej i oczywiście ściągania gotowych rozwiązań. Zresztą uczniowie wymieniają się wszystkim, co ich interesuje: zdjęciami, filmami, muzyką. Komentują na bieżąco szkolne i pozaszkolne wydarzenia. Jeżeli nie komputer, to przynajmniej smartfon musi być stale w zasięgu wzroku. Najbardziej mnie zadziwiła zaobserwowana ostatnio umiejętność jazdy na rowerze i jednocześnie pisania wiadomości SMS. Dorośli tak nie potrafią.

Internet wkroczył w nasze życie społeczne i ono się w wielu aspektach istotnie zmieniło, ale nadinterpretacja zalet używania sieci w każdej dziedzinie, traktowanie stron www jako wszechnicy wiedzy wszelakiej skutkuje tym, że zapominamy, iż ta sieć jest tylko kopalnią wiadomości, czasem wartościowych, rzetelnych i wiarygodnych, ale czasem niestety fikcyjnych, błahych, miejscem łamania praw 
autorskich i zachowań patologicznych (Kiedrowicz 2012). Łatwość kopiowania w świecie cyfrowym stwarza złudne poczucie, że prawie wszystko, co można znaleźć w Internecie, można skopiować i użyć do własnych celów. Skoro można skopiować piosenkę, to można skopiować wypracowanie czy rozwiązanie zadania. Przecież nikt nie widzi, co się robi w cyfrowym świecie.

\section{PODSUMOWANIE}

Potrzebne są zmiany w szkolnictwie. Szkoła utraciła na rzecz Internetu swą decydującą rolę dostarczyciela wiedzy. Nauczyciele utracili prestiż. Uczniowie mogą zdobyć wiedzę w każdej chwili, nie wychodząc z domu. Traktują szkołę z coraz większą niechęcią. Opinie naukowców i badaczy nie pozostawiają złudzeń:

polska edukacja nie kształci kapitału intelektualnego i społecznego na miarę naszych czasów i nie przygotowuje do przyszłości, tkwiąc w XIX-wiecznej koncepcji z systemem klasowym, nauczaniem przedmiotowym, wiedzą rozumianą jako zbiór prawd niepodważalnych do zapamiętania, rolą nauczyciela jako egzekutora, dyscypliną jako wartością cenioną wyżej niż umiejętności (Klas-Markiewicz 2015, s. 466).

„Mimo reformy programowej programy nauczania wszystkich przedmiotów są przeładowane, więc szkoła przerzuca ciężar nauczania na rodziców (system korepetycji, kursów, dodatkowych lekcji), sama tkwiąc w wielkiej fikcji” (Postek 2005, s. 20). „Sieć zachęca do niemyślenia. Materiały w Internecie są czytane szybko, fragmentami, bez refleksji” (Gogołek 2015, s. 107).

W swojej pracy ze studentami obserwuję konsekwencje tych zjawisk. W czasie sprawdzianu z wiedzy dotyczącej edukacji przyrodniczej (na Wydziale Filologiczno-Pedagogicznym) kilka studentek z 3 semestru pedagogiki na pytanie o ssaki żyjące w środowisku leśnym nie potrafiło wymienić żadnego ssaka lub co najwyżej jednego ewentualnie dwa. Przecież te same studentki, mając 7 czy 8 lat w czasie zajęć szkolnych, bez problemu pewnie odpowiadały na pytanie, jakie zwierzęta żyją w lesie. Kilkanaście lat kontaktu ze szkołą całkowicie oduczyło je myślenia. Inny przykład zaczerpnięty z zajęć ze studentami z Wydziału Informatyki. Na kolokwium sprawdzającym przy komputerze umiejętności z podstaw programowania studenci mieli napisać program, który kodował wprowadzone hasło kodem Cezara. Zasada kodowania została wytłumaczona. Po napisaniu zadania na tablicy odczekałem kilka minut i sprawdziłem, co robią na swoich komputerach. Okazało się, że prawie wszyscy mieli włączone wyszukiwanie w wyszukiwarce Google i wpisane hasło „kod Cezara” (bądź „program kod Cezara” lub podobne). 
Oczywiście próbowali wyszukiwać informacje po kryjomu, w sposób nierzucający się w oczy. Brak wiary we własne możliwości czy wykorzystywanie technologii, która tak ułatwia życie i jest dla nich czymś tak naturalnym jak powietrze? Tylko jak takie postawy pogodzić $\mathrm{z}$ zasadami etyki?

\section{LITERATURA}

Gogołek W., 2015, (Nie)bezpieczny wymiar IT w edukacji. W: W. Czerski, R. Wawer (red.), Nowoczesne media w przestrzeniach edukacyjnych. Lublin, Wydawnictwo UMCS.

Halawa M., 2010, Połaczeni i podłaczeni: młodzi w sieci, opublikowano: www.gazeta. pl [dostęp: 15.12.2015].

Kiedrowicz G., 2009, Technologia informacyjna w turystyce i rekreacji. Radom, Wydawnictwo Politechniki Radomskiej.

Kiedrowicz G., Ziębakowska-Cecot K., 2012, Edukacja medialna i informatyczna wobec zagrożeń świata wirtualnego. W: S. Bębas, J. Pils, J. Bednarek (red.), Patologie w cyberświecie. Radom, Wyższa Szkoła Handlowa w Radomiu.

Klas-Markiewicz A., 2015, Nauczyciel w obliczu rewolucji edukacyjnej. W: E. Sałata, M. Mazur, J. Bojanowicz (red.), Edukacja wczoraj-dziś-jutro. Radom, Wydawnictwo Uniwersytetu Technologiczno-Humanistycznego w Radomiu.

Melosik Z., 2003, Kultura popularna jako czynnik socjalizacji. W: Z. Kwieciński, B. Śliwerski (red.), Pedagogika. Podręcznik akademicki, t. 2. Warszawa, PWN.

Postek H., 2005, Polska szkoła wymaga głębokich zmian. „Wychowanie na co dzień”, nr 12.

Press Kit Firmy Brainly, opublikowano: http://brainly.co/ [dostęp: 15.12.2015].

Spisywanie prac domowych, opublikowano: http://victor-junior.pl/forum/index. php?topic=20107.0 [dostęp: 15.12.2015].

http://sciaga.pl/ [dostep: styczeń 2016].

http://pracadomowa24.pl/ [dostęp: styczeń 2016].

http://pracadomowa.pl/ [dostęp: styczeń 2016].

http://odrabiamy.pl/ [dostęp: styczeń 2016].

http://zadane.pl/ [dostęp: styczeń 2016].

http://www.victor-junior.pl/ [dostęp: styczeń 2016]. 
THE IMPACT OF THE DEVELOPMENT AND MASSIVE DISSEMINATION OF PERSONAL DIGITAL DEVICES ON THE CHILDREN AND YOUTH'S BEHAVIOR AT SCHOOL

\begin{abstract}
Copying during lessons or when doing homework was present in the Polish educational system for a long time. Nowadays, the observed development of digital devices connected to the Internet increased the scale of this phenomenon considerably but, at the same time, caused the change of youth's attitude towards this issue. The students' declarations prove that whenever they can avoid working on their own, they copy and do it often.
\end{abstract}

Keywords: Brainly, homework, educational system 